\title{
THE COVID-19 PANDEMIC - A SOURCE FOR GEOPOLITICAL CHANGE? THE CASE OF EASTERN EUROPE
}

\author{
Oana - Antonia COLIBĂȘANU \\ National University of Political Studies and Public Administration \\ Department of International Relations and European Integration \\ Bucharest/ Romania
}

\begin{abstract}
The world's tectonics seem to be changing faster than before, considering the current Covid-19 pandemic. Understanding the general, global sources for change that drive the major powers' national interests is key to understanding Eastern European geopolitical trends. This research paper looks at the impact the Covid-19 pandemic has had so far on the world, considering the main geopolitical questions that have been raised during the last nine months since the pandemic started. It also addresses the pandemic effects on Europe, focusing on the challenges for Eastern Europe during the short and medium term. Conclusions refer to the way the regional balancing act changes, depending on how the EU, the US, China and Russia change position globally and how their strategies intersect with one another and with those of the countries in the Eastern Europe.
\end{abstract}

Keywords: COVID-19; EU geopolitics; global balance of power; Eastern Europe.

\section{INTRODUCTION}

This paper looks to start the conversation on the potential geopolitical changes and challenges that the Covid-19 pandemic has brought for Eastern Europe. To 
establish that, it first looks into establishing how existing geopolitical trends prior to the pandemic have been affected, at the global and then at the European level.

The paper outlines a review of the existing literature which refers to the way that the pandemic has affected and may affect society, considering both politics and economics as main resources for potential global insecurity. The literature review also looks to highlight the shortcomings of the public and scientific conversation on the contemporary pandemic. To establish the major geopolitical questions put forth during the pandemic, a close readership on existing documentation was done - articles (both media and academic articles), working papers, position and policy papers, studies done at the request of national and international institutions as well as public discourses of national and international political leaders were read through, aiming at establishing common themes for the public discourse.

The research method employed to reach conclusions was based on close monitoring of events (as highlighted in the media and scientific literature available) but also on putting together a focus group which facilitated discussion with peer researchers and experts in geopolitics. Analysis was sustained through the focus group findings and SWOT techniques, making it easy to highlight major questions relating to regional stability in Eastern Europe. While it is yet hard to point to specific details, numbers that refer to future development for the countries in the region, the research methodology employed facilitated establishing the main directions for change on the short and medium term, while also emphasizing the constant elements referring to the geopolitical balance in the region and ultimately, in Europe.

\section{LITERATURE REVIEW}

Since February 2020, when it was announced that the world is entering a global pandemic, due to the exponential spreading of the Covid-19 virus, we have acknowledged that, besides the pandemic's implications for the health system and for the pharmaceutical industry, the world will also experience economic 
distress. During the last months, we have witnessed a rapidly growing research and literature available on the economic consequences of Covid-19 (Brodeur et al. 2020). Available literature points out to the fact that the current pandemic will unequally hit all economies (Ozili and Arun 2020), unequally hit sectors of the economy (Fernandes 2020) and ultimately, it will unequally hit age groups and communities, considering their geographical location (Barrot, Grassi and Sauvagnat 2020). Considering the data available, it is yet difficult to establish concrete measurements the economic distress, while it is safe to say that we will have at least several scenarios to consider, when we talk about the global macroeconomic evolution (McKibbin and Fernando 2020).

The global economic distress is said to cause socio-political effects worldwide. Dayrit and Mendoza (2020) have concluded in their research that enhanced control over the most affected areas during the first months of the health crisis is most effective in keeping socio-economic impact to the minimum on the long term. However, for control to be effective, trust in government plays a key role. Bargain and Aminjonov (2020) have shown in their paper that the Europeans residing in regions with high level of trust have decreased mobility related to non-necessary activities compared to those living in regions with lower levels of trust. In the same time, research done by Barrios et al. (2020) and Durante et al. (2020) concluded that those who live in regions characterized by high civil culture are also engaging in more social distancing.

While there is evidence of socio-economic problems influence the political environment, specific research done during the last months refers to particular countries or particular hypothesis referring to human behaviour. The geopolitical effects - encompassing the social, economic and political reactions at the national level as well as the pandemic effect on international relations have not yet been discussed. While efforts to contextualize the pandemic social effects have been made (Lupton 2020), there is little scientific work on integrating findings and try to establish broad development trends referring to global geopolitics. 


\section{METHOD}

This exploratory qualitative study examines the geopolitical effects of the pandemic, using three main approaches. First, the paper starts with a qualitative study of the relevant documents, reports and analysis with the purpose of highlighting the major topics launched during the first six months of the pandemic by public personalities in international affairs, be it writers, researchers, philosophers or political personalities. A close monitoring system of international media has been installed, with the scope of establishing major topics available for the consumption of the large public. In the same time, topical interests were established based on the agenda of various international conferences on global affairs and geopolitics in particular, held between March October 2020. Policy papers as well as public discourses of global leaders were also closely read, with the same purpose.

Second, the paper considers the major evolutions in global affairs and, for that reason, it focused on a close monitoring of events pertaining to both economic and social affairs that may have had or might have a high impact on international affairs. A list of potential outcomes after the health crisis is over was drawn, given both the urgency needed to tackle socio-economic problems and the geopolitical imperatives of the nation states considered in the research. In this paper, the health crisis is considered to continue as long as there is no cure or vaccine to stop the virus from spreading and consequently putting pressure on the health system infrastructure. In the same time, geopolitical imperatives are taken to be security related needs that a nation state must fulfil, considering peacetime conditions and their specific economic interests.

Third, focusing on Eastern Europe and considering the list of the major geopolitical questions as well as the constancy of historical patterns, a SWOT analysis was run, highlighting the limits of forecasting during the pandemic but also underlying several specific geopolitical trends in the region. For the SWOT analysis, the focus group method was employed for establishing challenges and patterns perceived by ten experts on foreign affairs. The group of experts was put together considering a fair representation of the regional security stakeholders and keep balance between the economic and political expertise. 
The group was formed by three experts from the US, two from Romania, two from Poland, one from Ukraine, one from Russia and one from Turkey. In the same time, considering academic backgrounds for each expert, the group was formed by three economists, three political scientists, two historians and two military officers.

As a result, a list of major geopolitical questions was drawn based on the first methodological approach, making it possible to understand the major global challenges that the world will be facing in the coming years. In the same time, an outline of the European major challenges and opportunities was drawn based on the second methodological approach. The SWOT analysis drawn by using the third methodological approach allows us to conclude the major geopolitical trends affecting the Eastern European region in the near future.

\section{A QUALITATIVE STUDY OF THE COVID-19 MAJOR QUESTIONS ON GEOPOLITICS}

The global pandemic, just as other previous similar events, will likely leave lasting socio-economic scars around the world in the years to come. But it also gives way to opportunities. So far, it underlined our societies' weaknesses, highlighting our systemic fragility (Durante 2020). In the same time, it has brought into discussion new questions about the way human society develops and is managed as a cohesive system, ultimately addressing several key geopolitical trends for the years to come.

Considering the existing documentation referring to the evolution of the international affairs worldwide during the Covid-19 pandemic, while there are many speculations made by journalists and analysts worldwide (Gaub and Boswinkel, 2020, p. 2), it is important to establish the common themes comprised in the documentation. To do that, we first need to establish the various ways in which the pandemic is treated. Robert D. Kaplan saying that "Covid-19 will be seen as a chapter break" (McTague 2020) especially by the historians, George Friedman underline the effects on business and the workforce will drive more 
pressure on governments to increase their protection policies (Friedman 2020) and Ian Bremmer underlines the dangers for globalization that covid-19 poses (Bremmer 2020). Kevin Rudd and Susilo Bambang Yudhoyono, focusing on Asia geopolitics underline the need for economic recovery before geopolitical balance be re-established, warning that Covid-19 has strongly deteriorated multilateral relationship network (Rudd and Yudhoyono 2020). In Europe, various think tanks like CEPS (Debuysere 2020), SIEPS (Youngs 2020) or Clingendael (Kortenweg 2020) focus on the social problems problems that corona health crisis has brought to light. Others, like the Robert Schuman Foundation, Cargegie Europe or Globsec have discussed and published reports related to the institutional and political functioning of nation states and international organisations (such as NATO and the EU) during Covid-19 health crisis. The study report issued by the Policy Department of the Directorate General for External Policies in September 2020 underlines that geopolitical developing trends, existing before March 2020 have stayed and, in particular cases, have accelerated (Gaub and Boswinkel 2020, p. 6), which has made it possible for us to misread the Covid-19 single impact.

Considering the abundance of discussions, debates and articles on the topic, there were three main aspects that refer to the intersection of politics, economics and security elements refering to the stability of national states. These make of geopolitical aspects launching broad questions for the years to come, of which three were selected as stand-alone common narratives.

a) First, the global power competition has accelerated, bringing forth new opportunities (along with new risks) for regional powers. As all countries have focused on solving the Covid-19 health crisis at the national level, competition between regional players has not been put on hold. On the contrary, it has accelerated. This has been particularly visible in the borderlands, where the major powers' interests and their influences have become more visible during the last months.

We have witnessed increased instability - as it is the case of Belarus or Kyrgyzstan, while in the Caucasus, the frozen conflict between Armenia and 
Azerbaijan over Nagorno Karabakh has warmed up (Crisis Group 2020), considering the clashes during September - October 2020. Of note is that while Lukashenko was installed president of Belarus, protests against the regime, claiming that democratic rights have been fraud during the recent elections continue even in November 2020, two months after the elections (Brzozowski 2020). As the winter approaches, the authoritarian regime, even if it secured Moscow's backing, braces for more protests considering the economic problems and the general social discontent existing in the country (Slunkin 2020). The recent adoption of sanctions by the EU against personnel within Lukashenko's staff and companies associated with the regime is also likely to fuel increased conflict between the EU and Russia, leaving room for more instability to come. In the Indo-Pacific, since April, the Quad (comprising Japan, Australia, India and the United States) launched a number of meetings meant to cement the alliance's goals, considering the complicated reality of the region in flux (Orchard 2020). Its potential to limit Chinese influence and deter Chinese attempts to establish military dominance in the region - especially if other regional states such as Singapore, Taiwan and South Korea could be enticed to join - remains high, but certainly specifics are still to be established (Madan, 2020). In the same time, India has entered a technical recession in the first half of the year. Japan is continuing to promote multilateral cooperation in the region. Considering Chinese military moves from the East China Sea to the South China Sea and into the Himalayan borders, both India and Japan call for the establishment of a "new ocean and security agenda" to be developed (Chansoria 2020).

b) Second, the specific social needs brought by the health crisis have naturally speeded up systemic restructuring in all economic sectors and nation states' governing institutions, even if in different amounts. Before the pandemic, we were talking about the need for new governance systems in line with the current needs imposed by digitization. We were also considering, theoretically, digital power to be a new domain for geopolitical research (Soesanto 2017, 3). The pandemic highlighted some of the systemic vulnerabilities associated to globalization and, as a result, the cyberspace quickly became a central preoccupation for all. 
During the first wave of the pandemic, in spring 2020, when lockdowns were imposed all over the world, the supply chains were hit first. More, the dependencies that made both production and consumption effective until March 2020 turned to be problematic, especially when it came to materials needed by the health systems to deal with Covid-19 infected persons. Besides masks and other protective equipment, medicines quickly became unavailable as demand was soaring (Kunt et al 2020). Digitization was no longer efficient in managing supply and demand - instead, it became a facilitator for information systems. In the meantime, working from home became the new normal - the cyberspace became the office space, but also the school's classroom and even the schoolyard. As our lives turned to the virtual, cyber-powered environment, a new set of questions had to be quickly answered, considering the legal infrastructure of each nation state (Collard et al 2020, 35). Some of them referring to children rights, but also to workers' rights, still remain to be answered.

Adaptation, however, became the new norm, while governing systems (of schools, companies, entire states) have apparently become more flexible. The restructuring process put forth the human being as the most important resource with the two facets of the critical infrastructures to become most important to reform: the healthcare system and the education system. If before the pandemic we had barely switched from human capital to human resources when talking about demographics, the pandemic made it clear that humans have become the most important resource for all nation states. Both the speed and the meaning (effectiveness) associated to systemic restructuring is strictly tied to the human resources implementing the reforms needed and thought through during the pandemic. This way, the human resources a nation state has (and invests into) is key to achieving competitive advantage, through innovation (Dasaratha 2020).

c) Third, because of the existing differences between classes, between the urban and the rural, between nation states when it comes to development levels, the current pandemic will only deepen social polarization. This, along with further insularization, will lead to 
increased protectionism and nationalism worldwide. However, solutions to manage it could lead to the discovery of governance models or, on the contrary, facilitate anarchic systems, giving birth to new kinds of risks and uncertainties.

Technological access, digitization is not the same everywhere on the Globe. Access to the internet and even the governing laws of internet access are different from country to country, underlying the characteristics of the new geography of the world, when it comes to integration and communication. Nation states are using the internet to project influence while protecting their interests, companies are using the internet to effectively run their businesses and individuals are using it for daily information and communication (Papanikolaou and Schmidt 2020). Each actor, each individual depending on its needs and interests, is using technology in a different manner.

In the same time, accessibility differs from one place to another, depending on the terrain and the level of economic development of the specific area (Coven and Gupta 2020, 11). While it is common for a Western European living in a rural setting to have access to the internet, it is less common for someone living in a rural setting in Central Asia to have such access. However, urban areas offer similar services to their inhabitants - living in an urban area in Canada is not much different than living in a Chinese urban area, when it comes to services available (Chiou and Tucker 2020, 12).

With the pandemic, existing similarities but also existing differences were underlined. As economic problems are likely to follow the current health crisis, considering that less funding available for investing in the less developed areas, such differences will likely continue to deepen. The poorer regions will adapt their governance systems considering their specific realities. Therefore, coordination and even communication of these less developed areas with the rest of the world could decrease as differences between them and the rest of the world increase, ultimately making it possible for "islands" of civilization to coexist with a world of similar urban areas (Papanikolaou and Schmidt 2020). This will only make the act of governance harder than it was before. 
Differences between classes will also grow. During the first six month of the pandemic the statistics pointed out that the Globe's wealthiest persons have become wealthier. In the same time, in the U.S. it was registered a record high unemployment rate - and the U.S. was not alone in reporting such numbers. The growing differences between classes has started long before the pandemic started - the 2008-2010 economic crisis only made matters worse (Corsetti and Guerrieri 2020, 21-24).

The economic problems thought to increase in 2021 are expected to hit the middle class and increase the existing gap between the poorest and wealthiest classes (Binder 2020). Consequently, nationalism and radicalism will only continue to grow - with little common political views existing in between the classes belonging to the same society. This too, will increasingly make the act of governance more difficult. The situation could, ultimately, build up support for new governance models that accommodate conflicting views - or, on the contrary, result in growing social instability.

\section{AN EMPIRICAL STUDY OF EUROPEAN GEOPOLITICS}

\subsection{A qualitative assessment of the European Union core geopolitical questions}

In Europe, two main geopolitical events were to mark 2020, before the pandemic started: Brexit and the negotiation of the so called "Green Deal" - the multiannual financial framework for the EU. Both were to set the EU for a "geopolitical" future, as the new leadership in Brussels announced at the end of 2019 (European Council 2020). Both events were said to make the EU stronger as the two deals were to find ways for a much-needed growth in spite of the problems both the economic crisis of 2010s and Brexit brought. As the EU has gone through a decade of economic problems, everyone in Europe looked to the newly appointed Commission and Parliament visions as a chance for the EU's fresh restart (or reset) (Gaub and Boswinkel 2020, p. 11).

In the beginning of 2020, both France and Germany seemed to have decided to retake leadership of the EU or at least seriously start debating about its 
development, its structures, its rules, its goals. The newly appointed President of the Commission Ursula von der Leyen had announced that the green economy and digitization will become the core of European development, proposing that most EU funding be channelled for the two sectors. Research \& development was regarded as a key area when it came to security related investments. Germany and France were both talking about ways to have the EU develop into a security (and even military) alliance, considering the changes taking place within NATO and given the tension between the US and Western Europeans (Youngs 2020).

Relations between the U.S. and the Western European countries have increasingly become tense as since 2009 the U.S. started asking that all NATO members increase their defence spending, considering the existing imbalance between the Alliance national capabilities (New Atlanticist 2020). This followed NATO exercises and NATO operations where it became clear that the EU was heavily reliant on the U.S. for its security. In 2014, at the Wales Summit, NATO members have consensually agreed to increase defence spending to $2 \%$ of their GDP within a decade (NATO Summit Declaration 2014). Each member state was to consider its own shortfalls with respect to NATO capabilities.

However, while France, Germany and other European states realistically admitted the need to increase their own defence capabilities, both their national political and socio-economic realities were keeping the defence sector among the least important sectors when it came to government spending. There were always other priorities for the state to allocate funding to. While there was no visible danger to their security, these countries' population has been facing important socio-economic problems. The 2010 economic crisis has slowly transformed into an existential crisis for the EU and its member states, considering the structural problems their economies have faced since then.

However, it is not by chance that the U.S. started asking that its Transatlantic allies grow their defence capabilities in 2009. The U.S. was facing similar economic problems after the 2008 financial crisis. As the US socio-economic problems deepened after the 2008 financial crisis, Washington had to focus on finding solutions for solving the country's internal matters first and foremost (McTague 2020). In 2009, the U.S. was talking about "Pivoting to Asia", as 
problems at home had more to do with China and its economic model than anything else. Protectionism (and nationalism) increased even more as socioeconomic problems pointed to wealth inequality in the early 2010s. With the U.S. becoming a net exporter of oil in 2019, it had no reason to keep being the "global policeman" or be engaged in areas like the Middle East - it only had to make sure that it controls strategic alliance structures and is able to keep its shores safe from outside dangers (Meyer 2019).

The American slow "withdrawal home" during the last decade meant that the U.S. would keep being engaged, together with its close partners, in those regions of the Globe where it had a strategic interest to be engaged. For the U.S. it is important that Europe remains stable, considering it is its most important economic partner. Its strategic goal in Europe is that no particular power dominates the continent. Instead, the balancing act between major powers keeps it safe, as long as Europe continuing to be non-conflictual. The UK remains the U.S. key ally for European and global operations, while Russia remains the key threat to European stability. In the same time, as China increases its power and seeks to entry the European market, it remains a distant - but a real competitor in what regards the European balancing act (Turcsányi 2020).

From the European point of view, the EU is slowly beginning to realise the changing facets of globalization. While during the first two decades after the end of the Cold War, Europe benefitted from globalization as trade and investment were increasing, the 2010s brought the realization of the negative effects of globalization. Not only dependencies, but also increased economic competition made it difficult to profit from the existing global system. In 2019, during the EU-China Summit, China has changed roles from the EU perspective - and instead of being an "economic partner" has officially become a "strategic competitor and systemic rival" (European Council 2019). The EU maintains a high dependency on Russia when it comes to its energy supplies. But the EU relations with Russia have been strained since 2014 because of Russia's illegal annexation of Crimea as the EU has regularly renewed sanctions against Russia since (EU EEAS 2020).

Indeed, the EU Commission setting the goal for the EU to become geopolitically relevant comes as a reaction to the major powers' coercion acts against the EU's 
economic interests. Following the US withdrawal from the Iran nuclear deal in 2018, the EU could not hold its trading relations with Iran even if its members' economic interests were favouring such relations. The export controls that both China and the US currently use mean that European companies have to increasingly request authorization from either Beijing or Washington to export their products to third countries - simply because of the number of products in their supply chain coming from China or the US. In 2019, China has threatened with using punitive tariffs on cars to pressure Germany into accepting a bid by Huawei to build the country's 5G infrastructure. Even Russia has banned the imports of a vast array of agricultural products coming from Poland after the EU imposed sanctions in 2014 (Pezzuto 2020).

The pandemic only underlined the need for the EU to build itself up into a geopolitical player. Or at least into a geo-economic one - as building military capabilities needs longer than a few months (or years). The external pressure will only grow further, considering the current US-China trade war as well as the main geopolitical trends globally. A recent example for the external pressure and attempted coercion is the Chinese threat to curb medical supplies to the Netherlands in April 2020, just as the pandemic started and lockdowns began in Europe, in order to force it to reconsider changing the name of its Taiwan office. The pandemic has made what the EU Commission proposed in 2019 - for the EU to step up to the global game and become geopolitically relevant - ten times more urgent. Europeans are being asked to become more pragmatic about their future and develop policies that respond to various types of economic coercion coming from outside of the EU market (Subotić 2019).

However, the EU is challenged also from within. While the EU market is the largest on the Globe, there are no shared strategies or goals between the EU members. Even before the pandemic, the start of the negotiations regarding the next EU multiannual financial framework was proof for its fragility - the EU members were not only distrusting each other, but all seem to distrust the chances for the EU to grow into an economic powerhouse (Borrell 2020).

In fact, discussions around the topic showed disparities between the West and the East and between the Northern Europe and the Southern Europeans. Simply put, the Northern member states (also the most developed EU states) are no 
longer willing to pay for the development of the Southern, poorer ones. More, the West, formed of the "old" member states - states like France or Italy, finding themselves under economic distress, are no longer willing to accept that the new comers in the East need funding more than they do for developing their economy. Discussions about the EU regionalization, a topic that used to belong to those holding Eurosceptic views several years ago, have become mainstream in European politics during the last five years (Gaub and Boswinkel 2020, 35-44). In the beginning of the pandemic, the EU members' first reaction was to close down borders in order to safeguard their medical stocks. The prerogative to protect the population's health belongs to the national state and the EU could only take a managing role, helping to create structures where resources could be shared. But nationalism is not to be neglected when it comes to basic security needs. Italy's cries for humanitarian help seemed to be met by Chinese and Russian responses sooner than they were met by responses coming from their peers in the EU: Germany or France. While the situation changed in a few weeks and the EU member states managed to coordinate their actions and help one another, including by putting some of their medical stocks in common, the lesson learned was that protectionism prevails when national security is at stake. After the first lockdown ended, in July 2020, the EU member states agreed to allocate a 750 bn euros recovery fund (Next Generation EU) for "the survival of the EU project". The fund is set with the objective to help weaker European economies recover from the very deep recession to follow the severe health crisis, and to help them decrease the economic gap vis-à-vis the more developed European countries. This event might set a turning point for the EU since it is the first time that the member states are committed to issuing a sort of EU-bond - the corona bonds, on the market. Through debt mutualisation, the EU Recovery Fund is also a breakthrough for the creditworthiness of the EU member states and the sustainability of their sovereign debt ratings. The announcement has had a positive effect: it has reduced the threat of a potential downgrade by the credit rating agencies for the southern European economies. More importantly, the agreement might take the EU closer to becoming a political union - as through the (successful) launch of corona-bonds, the EU would become closer to a fiscal union than ever before. The euro could also 
become a reserve currency - and the central banks would have access to a new set of large liquid bonds to buy. However, political support for the Next Generation EU package is still under construction and still fragile (Bremer et al 2020).

To help the member states address the economic problems that they are facing during the pandemic, the EU economic governance rules have also been temporarily suspended (i.e., the Stability and Growth Pact and State Aid rules). The EU has agreed on offering its member states the European Stability Mechanism (ESM) funds with "light" conditionalities and the SURE fund (a European instrument for temporary support to mitigate unemployment risks in an emergency) has also been put at members' disposal when needed. All this is done while lockdowns are hoped to be avoided during the second wave of the pandemic in Europe, considering that stringent lockdowns are one of the downward risks to economic recovery.

During the pandemic, the decision-making process in the EU has proved to be both flexible and adaptive. While there are a number of steps to be achieved for the EU Recovery Fund to be fully formalized (the EU Treaties ask for EU member states' Parliaments to ratify the agreement on the EU Recovery Fund), Brussels has managed to push through difficult decisions. A relaxation of regulatory requirements for the European companies to access funding is also envisioned (Bradshaw and Thomas 2020).

However, while the EU bureaucracy and governments may design the best relief processes for the economy to bounce back, it is the economic actors, the general public who will ultimately decide what works and what doesn't - making for the economy to bounce back, or not. One thing is certain: the sooner the EU grows its unity and starts its economic recovery, the more chances for it to truly play an important geopolitical role globally. If it fails to do so, its fragility will let nation states competition (and not only regional powers competition) prevail.

\subsection{A qualitative study of the Eastern European geopolitical challenges}

The pandemic has created the conditions for the EU member states to increase their cooperation in the economic sphere, but their strategic goals and their 
interests are not aligned. While they share the common market, their perception on what constitutes a security threat differs (Kaplan 2018, 24). For example, France or Italy will look to the Mediterranean for evaluating their security threats and will not see Russia among them, while Poland and Romania consider Russia as the main potential threat to their security. Germany, on the other hand, will consider Russia to be an economic partner while recognizing its aggressiveness. Germany - the export power-house of Europe needs to make sure it has a market to export to, and, as the U.S. becomes increasingly protective and potentially smaller (with socio-economic problems causing a decrease in consumption), it looks to China and Russia to establish economic partnerships, while also cautiously considering potential risks that could arise of such endeavours ( $\mathrm{O}^{\prime}$ Connor 2020).

All these visions influence the way EU alliances are forged and ultimately, the EU posture at the global level. For instance, the fact that the U.S. has threatened action against German state officials over Nord Stream 2 is often considered a coercive measure not only against Germany but also the EU, even if the EU Commission has spoken against Nord Stream 2, as well (Hackenbroich et al 2020). The public perception, also shaped by economic interests is most important in helping partnerships and organizations survive and develop.

In Eastern Europe, the public has seen the EU to be effective for the regional economic development. The same region has seen the U.S. as their main ally against the Russian threat, with all others in the EU having distinct and individual visions for their relations with Russia. This is why, as Western Europe and the US have come apart on security related topics, for the countries in Eastern Europe the balancing act between Brussels and Washington has become priority. In the same time, forging regional alliances that the U.S. supports has also been a key step for their defence strategy. Ever since 2014, when Russia lost Ukraine and consequently has illegally taken over Crimea to secure its presence in the Black Sea, it became clear that Eastern Europe has become the centre of gravity for battling influences between the West and the East and notably between the U.S. and Russia (Kofman et al 2017).

The pandemic has accelerated instability in the region. The events in Belarus and the Caucasus have confirmed both the Russian weakness and its aggressive 
manners (Walter 2020). In the same time, it has validated the fact that the Western - or American - Containment line has been moved from Central European Germany to Eastern Europe, currently encompassing a triangle of strategic agreements between the U.S., Poland and Romania. In July 2020, the U.S. has announced that it will withdraw its 12.000 troops from Germany in what it described as a strategic repositioning of its European forces. The U.S. is currently negotiating with Poland and Romania on further deployments as well as on new lines of cooperation with the two pivotal partners in Eastern Europe. As all appears to be in flux in the region, in order to understand and highlight the current geopolitical challenges in Eastern Europe, a review of the latest developments in the Baltic and the Black Sea wider regions is necessary. A list of major events prior to the covid-19 pandemic that drove current geopolitical trends is outlined below, while also trying to keep in mind the SWOT analysis framework, considering the scope of the research.

\subsubsection{The Baltic Sea region - current geopolitical challenges}

In the Baltic Sea Region, Russia is considered to be the main security threat for Poland, Lithuania, Latvia and Estonia. Since before 2010, Russian led hybrid warfare campaigns have been no surprise and part of the new normal in the region - but they intensified since 2014, as Russia has intensified its strategic information operations, or simply said its propaganda, in the region. Considering that the majority of the Russophone community in the region is relying on Russian media for getting their information, the scenario that has been most feared in the Baltic States is that where Moscow might covertly orchestrate or exacerbate a domestic incident involving the Russophone community to provoke a crisis. Moscow could then take advantage by the ensuing turmoil and intervene militarily to protect Russian minority. For Poland, such a scenario would be problematic given the imbalance between its forces and those of the Russian Western Military District (Shlapak 2016).

In light of these concerns, Poland has worked to secure its strategic partnership with the U.S. with whom it signed, in August 2020, an Enhanced Defense Cooperation Agreement (EDCA). In December 2019, the Baltic States - Estonia, 
Latvia and Lithuania, all NATO members, have agreed to establish a joint brigade with Poland as a framework country with the goal to strenghten the readiness of the Eastern flank. All countries in the region have integrated new concepts into their national security strategies that are designed to counter hybrid attacks coming from Russia or elsewhere. In the same time, Poland is also negotiating with the U.S. the addition of an extra 1000 troops to the already 4500 stationed in the country, considering the U.S. announcement in July referring to its European troops reposition strategy (Trevithick 2020).

The situation in Belarus is telling for how Covid-19 has accelerated instability in the region. The public demonstrations against Belarus president Alexander Lukashenko, ongoing for months now, have underlined the political and economic instability of the regime, considering Lukashenko resistance to implement any policies meant to protect the population against the Covid-19 pandemic. In power since 1994, Lukashenko managed to stay in power by controlling the opposition.

After years of economic stagnation, Belarus has been hit hard by the pandemic with more than 70,000 cases and over 700 deaths by the end of September. Lukashenko, afraid of the potential for an economic collapse to follow the health crisis if lockdowns were implemented, has stayed in denial of the virus and, confident in his own control and Russian backing, has refused to take any measures against Covid-19. Even if he officially took office on Sept. 23, Lukashenko's regime is still fragile and, while protests continue, Russia can do little to improve the situation. Moscow, after all, needs to make sure it takes control of Belarus without appearing to have violated its sovereignty something that becomes increasingly difficult (Zolotova 2020).

In the framework below, using the focus group method, we conclude on major elements that compose for a regional SWOT on the Baltic State. For the analysis, 10 (ten) analysts were selected for the discussion as follows: three from the U.S., two from Poland, two from Romania, one from Turkey, one from Russia and one from Ukraine. All have background in foreign affairs, although their expertise differs and they have been selected considering the need to bring together both economic and political expertise on security related matters. The SWOT framework considers the probability for an event to occur, based on the 
experts' answers. The events shown close to the left borders are more likely to occur, while events further to the right borders are less likely to occur. Therefore, results from the discussion with experts shows a minimal likelihood for the EU fragility to grow due to economic problems, while that event is considered to be a threat for the Baltic region stability. In the same time, the closer the event is shown to the center of the graphic, the more likely it is to be realised. For instance, it is more likely that the region stability suffers from economic distress than from the potential of increased Russian propaganda on the Russophone community in the Baltics.

Figure 1. SWOT - the Baltic Region (Poland, Baltic States)

\begin{tabular}{|c|c|}
\hline $\begin{array}{l}\text { STRENGHTS } \\
\text { US increased focus on Eastern Europe } \\
\text { The triangle alliance - the double } \\
\text { strategic partnership between Poland, } \\
\text { US and Romania }\end{array}$ & $\begin{array}{l}\text { WEAKNESSES } \\
\text { The Russophone community - the } \\
\text { potential Russian propaganda } \\
\text { The potential economic distress/ } \\
\text { instability after the pandemic }\end{array}$ \\
\hline $\begin{array}{l}\text { OPPORTUNITIES } \\
\text { Negotiations with the US - troops } \\
\text { Negotiations with the EU - funding }\end{array}$ & $\begin{array}{l}\text { THREATS } \\
\text { Russian weakness transformed into } \\
\text { aggressive tactics } \\
\text { Negotiation with the EU on behalf of } \\
\text { Poland - funding (rule of } \\
\text { law/political debate) } \\
\text { Belarus - the potential for continued } \\
\text { instability } \\
\text { Ukraine - the potential for renewed } \\
\text { conflict in Eastern Ukraine } \\
\text { EU potential for an increased fragile } \\
\text { estate (economic problems) }\end{array}$ \\
\hline
\end{tabular}

Source: author's work, based on the results of the focus group discussion 
Poland and the other Baltic States sees the situation in Belarus as an opportunity for the country to enter their sphere of influence - the EU's or, generally considered, the Western sphere of influence. However, while both Poland and Lithuania have vocally supported the opposition to Lukashenko, there is little else that they can do. While Belarus has tried to forge ties with the EU, its dependency to Russia is still high, especially in what regards its energy supplies. Poland and Lithuania may want a more European Belarus, but they are facing their own socio-economic problems and have no specific tools or ties to support the Belarusian economy, even if the regime changes. In this regard, the Belarusian case could be a threat - pulling Poland and the other Baltic states into a trap where they'd become involved in having to support a very weakened Belarus, still much dependent on Russia at a time when they need to focus on their own economic recovery.

The challenge the Poland and the Baltic states face is an unstable political and economic environment in Belarus that adds up to an unstable, problematic Ukraine. Instability in the two countries will drive the EU member states push for more EU involvement in the region at a time when their Western counterparts are focused on internal reconstruction of the EU. The risk for a new crisis to appear in the EU neighbourhood is associated with increased fragility of the EU as a bloc, considering the EU is currently focusing on its own resilience.

\subsubsection{The Black Sea region - current geopolitical challenges}

The Black Sea region is the site of the two Russian recent ground combat operations, in

2008 and 2014, and a critical transit area for Russian maritime access to Syria. Because of this, the Black Sea looks to hold the key to the European equilibrium, as it represents the flashpoint between the West and Russia. More, Ankara's limited cooperation with Russia in the Middle East, while its ties with Western European powers are weakening and its relationship with the U.S. is increasingly complex has made of the Black Sea key for everyone in Eurasia to watch during the last few years (Colibasanu 2020). With the U.S. withdrawing from the Middle East and Turkey aspiring to become a regional power, while 
Russia has, since 2014, expanded and modernized its Black Sea fleet has made the region a priority for Western analysts and decision-makers who are working in the general (and generous) domain of strategic planning.

Russia's Black Sea fleet now includes new cruise-missile-capable diesel submarines and frigates as well as deployments of air and coastal defense assets to Crimea. Russia has also deployed additional ground troops to the Southern Military District (Gorenburg 2018). Turkey, on the other hand, has announced its neo-Ottoman policy and has made itself visible on all topics discussed in and around the Black Sea. The pandemic, causing a record drop of the oil price and economic problems for everyone, has hit both the energy producers and energy transit countries. In other words, the pandemic has weakened the economies both Russia and Turkey - something that increased their need to appear strong (for the public eye) in their ability to project power in their borderlands. The current crisis in Nagorno-Karabakh carried on by energy producer Azerbaijan, supported by Turkey and Armenia, supported by Russia is just another facet of both Russia and Turkey seeking to maintain their posture in the region, even if it appears that without the U.S. intervention they are now unable to end the fighting (Friedman 2020a).

While Turkey is a NATO ally and its relationship with the U.S., even if increasingly complex, remains key for its strategy in the region, Russia has remained the most important threat for the regional stability. Russia keeps a large array of non-military instruments of influence in the Black Sea region that would undermine the unity of a military initiative. Therefore, the regional security needs to be regarded beyond the military realm. In a recent paper released by RAND Corporation with regards to Russian power in the Black Sea, it is noted that among the Black Sea countries, Romania is the only country that "will have the will and the capability to contribute to a regional military initiative in the Black Sea" (Binnendijk 2020). In the same time, the RAND study notes that "in light of the potential avenues for (Russian) influence that the new TurkStream pipeline might create in Turkey, and potentially Bulgaria, robust energy dialogues with both countries on their gas hub aspirations could identify options to maximize regional interconnectors and alternative sources of gas", 
underlying the fact that energy security in the region is closely tied into the regional geopolitical competition (Binnendijk 2020, 14-23).

The current pandemic has rushed Turkey into a position where it needs to expand its power to maintain internal stability and resist the power shifts in the Middle East and beyond. This has happened although its resources have diminished. In the same time, Turkey's attitude toward regional affairs and its need to cooperate with Russia to protect its interests has placed Romania into a key position for the U.S. interests. The military base in Kogalniceanu, Constanța - initially a transit base that the American military used for its operations in Afghanistan, has increased its role during the recent years, as the U.S. has increased its participation in regional exercises and the port of Constanța received periodic visits by U.S. vessels (Woody 2018). The pandemic, considering the regional events, rushed the need for bilateral relations between the U.S. and Romania to become more visible. To a certain extent, the current events in the Caucasus and the potential for new rising problems in the region or elsewhere, in Central Asia, as the pandemic weakens both Russia and China, has put more pressure on the U.S. to confirm its engagement in the Black Sea region.

To establish what is perceived to be the major challenges for regional stability in the Black Sea, using the same focus group discussion for when challenges for the Baltic Sea were discussed and the same manner of representation, we obtained the results in the table below.

Figure 2. SWOT - The Black Sea Region

\begin{tabular}{|l|l|}
\hline \multicolumn{1}{|c|}{ STRENGHTS } & \multicolumn{1}{c|}{ WEAKNESSES } \\
$\begin{array}{l}\text { US increased focus on Eastern Europe } \\
\text { The triangle alliance - the double } \\
\text { strategic partnership } \\
\text { between Poland, US and Romania }\end{array}$ & $\begin{array}{l}\text { The potential for Turkish propaganda } \\
\text { The potential for a complex approach } \\
\text { needed (in management and tactics) } \\
\text { coming from a more heterogenous } \\
\text { socio-economic region - comprising } \\
\text { both the Caucasus and the Balkans } \\
\text { The potential for sustained Russian }\end{array}$ \\
\hline
\end{tabular}




\begin{tabular}{|l|l|}
\hline & $\begin{array}{l}\text { propaganda } \\
\text { The } \\
\text { distress/instability after the pandemic }\end{array}$ \\
\hline $\begin{array}{l}\text { Negotiations with the US - troops } \\
\text { Negotiations with the EU - funding }\end{array}$ & $\begin{array}{l}\text { THREATS } \\
\text { Russian weakness transformed into } \\
\text { aggressive tactics } \\
\text { Increased socio-economic instability in } \\
\text { Turkey } \\
\text { Ukraine - the potential for renewed } \\
\text { conflict in Eastern Ukraine } \\
\text { EU potential for an increased fragile } \\
\text { estate (economic problems) }\end{array}$ \\
\hline
\end{tabular}

Source: author's work, based on the results of the focus group discussions

In early October 2020, as several Romanian delegations have visited Washington, we learned about other projects meant to reinforce the American presence in Eastern Europe - both in the military and the economic sectors. The U.S. and Romania recently signed a 10-year defence cooperation roadmap and an $\$ 8$ bn financing agreement for the modernisation of the Cernavodă nuclear reactors (Energy.Gov 2020). In the same time, the U.S. announced another $\$ 7 \mathrm{bn}$ financing agreement dedicated to modernise and complete the motorway and railway infrastructure linking the Black Sea to the Baltic Sea (Turp - Balasz 2020).

On Oct. 26, it was announced that the U.S. and Bulgaria signed a memorandum of understanding considering Strategic Civil Nuclear Cooperation - pointing to the fact that Bulgaria will likely be using U.S. technology in developing its Kozloduy nuclear reactor. In the same time, the U.S. and Bulgaria also signed a 5G security agreement (Tanev 2020). While there was no mention of Belene nuclear project - which is currently developed in agreement with Russia, these announcements point to steps taken by the U.S. to limit Russian influence in the region. This is in fact one of the most important challenge for the Black Sea region: to make sure the Russian influence remains limited and that, considering its weakness, 
Russia doesn't increase its aggressive manners in trying to project power within the region.

As the pandemic has hit hard both the Russian and the Turkish economy and taking into consideration that one of the main geopolitical questions for the next years refers to the acceleration of regional power competition during the Covid-19 pandemic, the manner in which the two countries work to keep their stability and power will decisively influence the Black Sea region. The evolution of bilateral ties between the US and the countries along the Black Sea shores will determine regional stability as well.

It is notable that the Ukrainian conflict remains "de facto" frozen even if sporadic borderline attacks continue. This points to the fact that there are limited incentives for either party to engage into an agreed settlement. Russia hopes to go beyond Eastern Ukraine and retake influence in Kiev while the West (the EU and the US both) prefer that the current status be maintained, where they keep Kiev engaged, considering the limited resources available for going after Eastern Ukraine. This, in turn underlines a weak state characterised by a somewhat stable situation in Ukraine - which also poses specific security risks for both the Baltic and the Black Sea regions.

\section{CONCLUSIONS}

It is still early to discuss the socio-economic outcome of the current pandemic. It is certain that the pandemic has given way to social transformations and, to an extent, it has accelerated competition between global powers, setting new geopolitical trends or at least launching new geopolitical questions.

The three main layers of analysis considered in the current paper allow us to start the discussion on the future for Eastern Europe, after the pandemic, considering the potential opportunities but also risks associated with the events having taken place, so far, during the pandemic year of 2020.

The perspective for economic troubles for all nations, which will likely turn into social problems that will drive the restructuring of governance models, has created a powers' rush into the borderlands. While the major powers have used 2020 for marking their engagement into global and regional affairs, their further commitment will depend on the countries in the Baltic and the Black Sea 
regions. It remains to be seen whether the U.S. commitment to Eastern Europe will supplement the EU imposed patterns for transformation launched through the Next Generation EU and make it so that Eastern Europe takes the opportunity of the pandemic rush-in. Besides the specifics of each country in the region, development patters will be challenged by existing Turkish and Russian ties into the regional socio-economics.

An honest SWOT analysis - pointing out the strengths, the weaknesses, the opportunities and the threats for Europe and for the Eastern European region needs to allow for complex negotiations underway within the EU, as well as those that the countries in the region have with the U.S., to settle into decisions. Until that happens, we may, however, note several trends for the regional balance of power. First, the U.S. engagement in the region will increase along with the reinforcement of the new Containment Line in Eastern Europe, linking the Baltic to the Black Sea. The partnerships' triangle formed of the U.S., Poland and Romania will likely grow its role for regional governance, considering the growing ties between the three. This will open up the opportunity of economic development and structural reforms to allow better integration within the Eastern European extended region - from the Baltic to the Black Sea. In the same time, it will increase the potential for resistance in those areas and sectors where Russian influence is still active.

Second, the EU economic sovereignty may increase, considering that fiscal unity is envisaged by the EU Recovery Fund recently proposed and agreed upon. In the same time, more economic sovereignty is needed for the EU to cope with the US and Chinese competition, considering the growing protectionism at the global level. While the EU is representing more nation states, the common market that stands at the core of its very existence will likely ask for Brussels to implement protectionist measures, in order to match the other powers' policies. Considering the Western Europeans and the Eastern Europeans don't share similar economic development patterns, more EU economic sovereignty will also be challenging for the Union's member states, even if in theory, it should bring more benefits than problems. If, however, agreements become possible between all member states, more economic sovereignty will be the first step for increased political unity. 
Third, the energy sector will remain key for the EU integration and stability. The pandemic has not made the EU renounce its plans for a Green Deal - on the contrary. As an ambitious strategy, the Green Deal speaks of equal access to modern energy infrastructure for all in the EU - that is specifically important during crises like the one Europe is currently facing. The Green Deal also speaks of existing differences between the Western and the Eastern states. While specifics on EU funding through the Green Deal are still to be established, it looks like some of the Eastern European countries - Poland, Romania and even Bulgaria have recently decided to choose the U.S. for supporting the modernization of their nuclear energy production. In the same time, projects like the Nord Stream 2 or the Turkish Stream, all carrying geopolitical weight, will still be debated between the West and the East of Europe, while the U.S. will be siding with the Eastern European states. A resolution between the EU member states to such debates will give way for true integration and enhanced energy security for the EU. But that remains problematic.

Increased polarization is probably the most important challenge that Europe and that the Eastern European region in particular, will face. The differences between the rural and the urban environments, the differences between classes are likely to deepen as socio-economic problems will increase as the pandemic goes on in Europe and elsewhere on the globe. The most serious threat caused by growing polarisation refers to anarchism. In other words, entire areas inside these states could become un-governable.

The opportunity arising from such a situation, where we'll have growing polarization in Europe, refers to reformation, in the sense that governance models need to re-invent themselves. Traditional governance is considered to be outdated for some time: digitization and generally, increased dependencies between nation states and individuals, through technology makes it outdated. So, while it is likely that socio-economic problems increase the gaps already existing within the European society, they also give the opportunity for systemic restructuring. Leaders will need to adapt to the new realities and become creative in bridging such gaps, making use of the technological progress available. Interestingly, Eastern Europe has the human resource needed for sustaining technological progress - it remains to be seen how much of that 
creativity and adaptive abilities translates into political restructuring and whether that process ultimately builds positive change for the region.

\section{REFERENCES}

- Atlantic Council. 2020. "Taking stock: Where are geopolitics headed in the Covid-19 era?". The Atlantic Council. https://www.atlanticcouncil.org/indepth-research-reports/issue-brief/taking-stock-where-are-geopoliticsheaded-in-the-covid-19-era/.

- Binder, Carola. 2020. "Coronavirus Fears and Macroeconomic Expectations. Social Sciences Research Network". https://ideas.repec.org/a/tpr/restat/v102y2020i4p721-730.html.

- Binnendijk, Annika. 2020. "Understanding Russian Black Sea Power Dynamics Through National Security Gaming". RAND. https://www.rand.org/pubs/research_reports/RR3094.html.

- Borrell, Joseph. 2020. "The post-coronavirus world is already here". ECFR. https://www.ecfr.eu/publications/summary/the_post_coronavirus_worl d_is_already_here.

- Bradshaw, Tim and Daniel Thomas. 2020. "EU to relax state aid rules that hindered support for start-ups". Financial Times. https:// www.ft.com/content/b66167cf-e27d-45fb-9d66-d4c113265b3f.

- Bremer Björn, Theresa Kuhn, Maurits J. Meijers and Francesco Nicoli. 2020. "The EU can improve the political sustainability of Next Generation EU by making it a long-term structure". Vox EU. https://voxeu.org/article/improving-political-sustainability-nextgeneration-eu.

- Brzozowski, Alexandra. 2020. "How young people in Belarus have become the drivers of the protests". Euractiv. https://www.euractiv.com/section/politics/news/how-young-people-inbelarus-have-become-the-drivers-of-the-protests/. 
- Chansoria, Monika. 2020. "One year after Covid, there is a strategic and economic reset in the Indo-Pacific". https://japan-forward.com/one-yearafter-covid-theres-a-strategic-and-economic-reset-in-the-indo-pacific/.

- Chausovsky, Eugene. 2020. “Belarus, Russia-West Rivalry, and the Global Authoritarian Pushback". Center for Global Policy. https://cgpolicy.org/articles/belarus-russia-west-rivalry-and-the-globalauthoritarian-pushback/.

- Colibășanu, Antonia. 2020. "The Black Sea: The Key to Eurasian Stability?". Geopolitical Futures. https://geopoliticalfutures.com/the-black-sea-the-keyto-eurasian-stability/.

- Collard, Fabrice, Christian Hellwig, Tiziana Assenza, Sumudu Kankanamge, Martial Dupaigne, Nicolas Werquin and Patrick Fève. 2020. "The Hammer and the Dance: Equilibrium and Optimal Policy During a Pandemic Crisis". CEPR Discussion Paper. https:/ / papers.ssrn.com/abstract=3603962.

- Corsetti, Martin, Giancarlo Corsetti, and Luca Guerrieri. 2020. "Social Distancing and Supply Disruptions in a Pandemic". Federal Reserve. https://www.federalreserve.gov/econres/feds/social-distancing-andsupply-disruptions-in-a-pandemic.htm.

- Coven, Joshua and Arpit Gupta. 2020. "DISPARITIES IN MOBILITY RESPONSES TO COVID-19". https://static1.squarespace.com/static/56086d00e4b0fb7874bc2d42/t/5ebf 201183c6f016ca3abd91/1589583893816/DemographicCovid.pdf.

- Crisis Group. 2020. "De-escalating the New Nagorno Karabakh War". Crisis Group. https://www.crisisgroup.org/europe-centralasia/caucasus/nagorno-karabakh-conflict/containing-violence-southcaucasus.

- Dasaratha, Krishna. 2020. "Virus Dynamics with Behavioral Responses". ArXiv:2004.14533 [Econ, q-Bio]. http://arxiv.org/abs/2004.14533.

- Demirguc-Kunt, Asli, Michael M. Lokshin and Ivan Torre .2020. "The Sooner, the Better: The Early Economic Impact of Non-Pharmaceutical Interventions during the COVID-19 Pandemic". Policy Research working paper; no. WPS 9257: pp. 1-95. Washington, D.C.: World Bank Group. 
http:/ / documents.worldbank.org/curated/en/636851590495700748/TheSooner-the-Better-The-Early-Economic-Impact-of-Non-PharmaceuticalInterventions-during-the-COVID-19-Pandemic.

- Durante, Ruben, Luigi Guiso and Giorgio Gulino. 2020. „Asocial Capital: Civic Culture and Social Distancing during COVID-19". http://dx.doi.org/10.2139/ssrn.3611606.

- Elenev, Vadim, Tim Landvoigt and Stijn Van Van Nieuwerburgh. 2020. "Can the Covid Bailouts Save the Economy?". https://www.nber.org/system/files/working_papers/w27207/w27207.pd f.

- Energy.Gov. 2020. "U.S. and Romania Announce Initial Agreement on Cooperation for the Cernavoda Nuclear Power Projects and Civil Nuclear Power Sector in Romania". https://www.energy.gov/articles/us-and-romaniaannounce-initial-agreement-cooperation-cernavoda-nuclear-powerprojects-and.

- EU EEAS. 2020. “The EU non-recognition policy for Crimea and Sevastopol: Fact Sheet". https://eeas.europa.eu/headquarters/headquartersHomepage/37464/eu-non-recognition-policy-crimea-and-sevastopol-factsheet_en.

- European Commission. 2019. "EU-China: A Strategic Outlook". https:/ / ec.europa.eu/commission/sites/betapolitical/files/communication-eu-china-a-strategic-outlook.pdf.

- European Council. 2019. "A new strategic agenda for the EU 2019-2024". https:// www.consilium.europa.eu/en/eu-strategic-agenda-20192024/\#group-EU-in-the-world-zh3uey0ErW.

- European Council. 2019. "Joint statement of the 21st EU-China summit". https://www.consilium.europa.eu/en/press/pressreleases/2019/04/09/joint-statement-of-the-21st-eu-china-summit/.

- Friedman, George. 2020a. "Conflict in the Caucasus and the New American Strategy". Geopolitical Futures. https://geopoliticalfutures.com/conflict-inthe-caucasus-and-the-new-american-strategy/.

- Friedman, George. 2020b. "Storm before the Calm, America's discord, the coming crisis of the 2020s, and the triumph beyond". Black Inc. Publishers 
- Gaub, Florence and Lotje Boswinkel. 2020. "The geopolitical implications of the Covid-19 pandemic". European Parliament. https://www.europarl.europa.eu/RegData/etudes/STUD/2020/603511/ EXPO_STU(2020)603511_EN.pdf.

- Gorenburg, Dmitry. 2018. "Is a New Russian Black Sea Fleet Coming? Or Is It Here?". https://warontherocks.com/2018/07/is-a-new-russian-black-seafleet-coming-or-is-it-here/.

- Kaplan, Robert D. 2012. "Revenge of geography". New York: Random House.

- Kaplan, Robert D. 2018. "The Return of Marco Polo's World". New York: Random House.

- Kofman, Michael, Katya Migacheva, Brian Nichiporuk, Andrew Radin, Olesya Tkacheva and Jenny Oberholtzer. 2017. "Lessons from Russia's Operations in Crimea and Eastern Ukraine". RAND. https://www.rand.org/pubs/research_reports/RR1498.html.

- Kortemweg, Rem. 2020. "Are Europe's Leaders Ready for A Biden Presidency?". https://www.clingendael.org/publication/are-europes-leaders-readybiden-presidency.

- Meyer, Gregory. 2019. "US is net exporter of oil for first time in decades". Financial Times. https://www.ft.com/content/9cbba7b0-12dd-11ea-a7e662bf4f9e548a.

- NATO. 2014. "Summit Declaration Issued by the Heads of State and Government participating in the meeting of the North Atlantic Council in Wales". https://www.nato.int/cps/en/natohq/official_texts_112964.htm.

- New Atlanticist. 2020. "Trump hits out against Europe in coronavirus speech: The transatlantic alliance suffers". https://www.atlanticcouncil.org/blogs/new-atlanticist/trump-hits-outagainst-europe-in-coronavirus-speech-the-transatlantic-alliance-suffers/.

- Nye, Joseph S. Jr. 2020. "Post- Pandemic Geopolitics". https://www.projectsyndicate.org/commentary/five-scenarios-for-international-order-in-2030by-joseph-s-nye-2020-10.

- O'Connor, Tom. 2020. “China Calls Russia's Talk of Possible Military Alliance 'Positive,' with 'No Limit' to Their Ties". 
https://www.newsweek.com/china-calls-russia-talk-military-alliancepositive-1541817.

- Orchard, Philip. 2020. "The Indo-Pacific after Covid-19". Geopolitical Futures. https:/ / geopoliticalfutures.com/the-indo-pacific-after-covid-19/.

- Papanikolaou, Dimitris and Lawrence D.W. Schmidt. 2020. “Working Remotely and the Supply-side Impact of Covid-19". Working Paper No. 27330; Working Paper Series. National Bureau of Economic Research. https://doi.org/10.3386/w27330.

- Pezzuto, Ivo. 2020. „World Economy. Resilience or Great Reset?”. ICTF Magazine of the Association of International Credit and Trade Finance $\begin{array}{llll}\text { Professionals (ICTF). } & \text { September } 2020 & \text { issue. }\end{array}$ http://dx.doi.org/10.2139/ssrn.3710368.

- "Positive trade balance for September could affect America's ties with allies". Financial Times. https://www.ft.com/content/9cbba7b0-12dd-11eaa7e6-62bf4f9e548a.

- Regens, James L. and John S. Beddows. 2020. “The Covid-19 Pandemic and geopolitics". RealCleaDefences. https://www.realcleardefense.com/articles/2020/06/01/the_covid19_pandemic_and_geopolitics_115337.html.

- Rudd, Kevin and Susilo Bambang Yudhoyono. 2020. “For the G20 to overcome Covid-19's global health and economic challenges, four things must happen". South China Morning Post. https://www.scmp.com/comment/opinion/article/3110501/g20overcome-covid-19s-global-health-and-economic-challenges-four.

- Shlapak, David A. and Michael Johnson. 2016. "Reinforcing Deterrence on NATO's Eastern Flank. Wargaming the Defense of the Baltics". RAND. https://www.rand.org/pubs/research_reports/RR1253.html.

- Slunkin, Pavel. 2020. "Glass Half Full: The EU's Policy in Belarus". ECFR. https://ecfr.eu/article/glass-half-full-the-eus-policy-on-belarus/.

- Soesanto, Stefan. 2017. "Europe's Digital Power: From Geoeconomics to Cybersecurity". ECFR. https://www.ecfr.eu/archive/page//DIGITAL_POWER_PROJECT_REPORT_13_April_pages.pdf 
- Subotić, Strahinja. 2019. "A 'Geopolitical' Commission - what's in a name?". European Policy Center. https://cep.org.rs/en/blogs/ageopolitical-commission/

- Tanev, Mario. 2020. "Bulgaria signs 5G security declaration, MoU on nuclear energy with US". SeeNews. https://seenews.com/news/bulgariasigns-5g-security-declaration-mou-on-nuclear-energy-with-us-718425.

- The World Bank. 2009. "Reshaping Economic Geography". http:/ / siteresources.worldbank.org/INTWDR2009/Resources/42310061225840759068/WDR09_00_FMweb.pdf.

- Trevithick, Joseph. 2020. "The Pentagon To Beef Up Its Posture In Poland". The drive. https://www.thedrive.com/the-war-zone/35329/the-pentagonto-beef-up-its-posture-in-poland-add-1000-troops.

- Turcsányi, Richard Q. 2020. "Poll: The EU Has Solid Common Ground When It Comes To China". The Diplomat. https:/ / thediplomat.com/2020/11/poll-the-eu-has-solid-common-groundwhen-it-comes-to-china/.

- Turp - Balasz, C. 2020. "Is the US about to finance a motorway linking the Baltic and the Black Sea?". Emerging Europe. https://emergingeurope.com/news/is-the-us-about-to-finance-a-motorway-linking-thebaltic-and-black-seas/.

- Walter, Mike. 2020. "Podcast Series: The Heat - Belarus Protests". https://america.cgtn.com/2020/08/25/the-heat-belarus-protests.

- Woody, Christopher. 2018. "The US Air Force is spending big to upgrade bases near Russia and testing out a 'base in a box' to make it easier". Business Insider. https://www.businessinsider.com/air-force-upgradingeastern-europe-bases-testing-base-in-a-box-2018-8.

- Youngs, Richard. 2020. "Geopolitics and the Covid-19 pandemic: a distorted turn in EU external relations". Swedish Institute for European Policy Studies. https://sieps.se/en/publications/2020/geopolitics-and-the-covid19-pandemic/. 
- Zolotova, Ekaterina. 2020. "Moscow Plays it Cool with Belarus". Geopolitical Futures. https://geopoliticalfutures.com/russia-plays-it-cool-withbelarus/. 